\title{
Studies towards the Synthesis of Pentalenene: Mechanistic Insights into the Isomerization Phenomenon During RCM of MediumSized Rings
}

DOI:

10.1002/ejoc.201001475

\section{Document Version}

Accepted author manuscript

Link to publication record in Manchester Research Explorer

Citation for published version (APA):

De Bo, G., \& Markó, I. E. (2011). Studies towards the Synthesis of Pentalenene: Mechanistic Insights into the Isomerization Phenomenon During RCM of MediumSized Rings. European Journal of Organic Chemistry, 2011(10), 1859-1869. https://doi.org/10.1002/ejoc.201001475

\section{Published in:}

European Journal of Organic Chemistry

\section{Citing this paper}

Please note that where the full-text provided on Manchester Research Explorer is the Author Accepted Manuscript or Proof version this may differ from the final Published version. If citing, it is advised that you check and use the publisher's definitive version.

\section{General rights}

Copyright and moral rights for the publications made accessible in the Research Explorer are retained by the authors and/or other copyright owners and it is a condition of accessing publications that users recognise and abide by the legal requirements associated with these rights.

\section{Takedown policy}

If you believe that this document breaches copyright please refer to the University of Manchester's Takedown Procedures [http://man.ac.uk/04Y6Bo] or contact uml.scholarlycommunications@manchester.ac.uk providing relevant details, so we can investigate your claim.

\section{OPEN ACCESS}




\title{
Studies towards the synthesis of Pentalenene: mechanistic insights on the isomerisation phenomenon during RCM of medium sized rings.
}

\author{
Guillaume De Bo, ${ }^{[\mathrm{a}]}$ Istvàn Markò ${ }^{*[\mathrm{a}]}$
}

Keywords: RCM / Medium sized rings / Isomerisation / Grubbs catalyst / Pentalenene

\begin{abstract}
Isomerisation issues have been encountered during the RCM step of a new approach towards Pentalenene. This paper describes the mechanistic insights gained during the study of this side reaction from a substrate perspective.

[a] Université catholique de Louvain, Institute of condensed matter and nanosciences, 1 place Louis Pasteur, 1348 Louvain-la-Neuve, Belgium

$\square \quad$ Fax: $+32(0) 10 / 472788$

E-mail: istvan.marko@uclouvain.be

Supporting information for this article is available on the WWW under http://www.eurjoc.org/ or from the author. ((Please delete if not appropriate.))
\end{abstract}

\section{Introduction}

Since their disclosure in the mid-nineties, the first and second generation Grubbs metathesis catalysts have been widely used in numerous area of chemistry such as total synthesis, polymer preparation and material chemistry. ${ }^{[1-2]}$ The metathesis reaction appeared particularly relevant for the assembly of medium-sized rings, which have always been challenging to construct. ${ }^{[3]}$ However, double-bond isomerisation in the substrate, ${ }^{[4]}$ or in the product, ${ }^{[5-6]}$ has rapidly been reported as a side reaction in this transformation. ${ }^{[7]}$ Even though advantage can be taken of this process to perform a tandem metathesis/isomerisation procedure, ${ }^{[8]}$ the isomerisation phenomenon remains an undesirable side reaction which is not yet fully understood.

Several groups have shown that the most plausible mechanism involves a ruthenium hydride species. ${ }^{[9]}$ The proposed mechanism is presented in Scheme 1. The ruthenium hydride complex $\mathbf{B}$ (which can eventually originate from the metathesis catalyst $\mathbf{A}$ ) coordinates to the terminal olefin $\mathbf{F}$ to form the $\pi$-adduct $\mathbf{C}$, which is then converted to $\mathbf{D}$ by a 1,2-migratory insertion of the olefin in the $\mathrm{Ru}-\mathrm{H}$ bond. The isomerisation catalyst $\mathbf{B}$ is recovered after $\beta$ elimination of a hydride and decomplexation of the internal olefin G.
Isomerisation issues have been encountered during the RCM step of a new approach towards Pentalenene. This paper describes the mechanistic insights gained during the study of this side reaction from a substrate perspective.
A $[\mathrm{Ru}]=\mathrm{CH}_{2}$

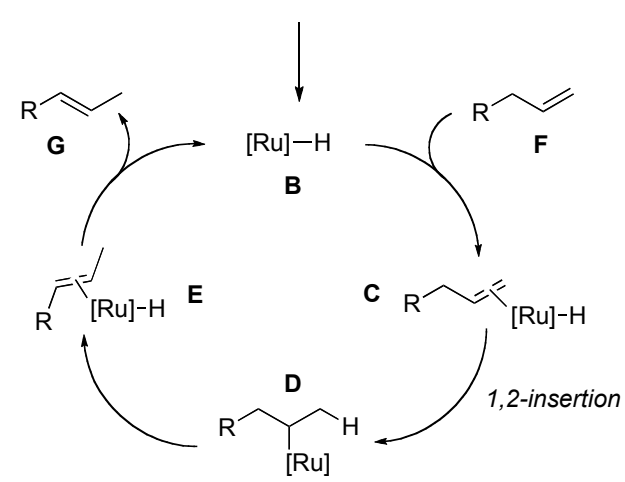

Scheme 1. Putative isomerisation mechanism.

As suggested by this mechanism, the $[\mathrm{Ru}]-\mathrm{H}$ species can be generated by decomposition of the active metathesis catalyst $\mathbf{A}$, but it can also have a different origin. In fact, two main sources of $[\mathrm{Ru}]-\mathrm{H}$ can be distinguished: the $[\mathrm{Ru}]-\mathrm{H}$ is present as an impurity in the initial catalyst or it is formed during the reaction. In the first case, the $[\mathrm{Ru}]-\mathrm{H}$ is generated during the synthesis of the catalyst, and hence, can be found as traces in the final compound. Indeed, numerous synthesis of the Grubbs catalysts imply a $[\mathrm{Ru}]-\mathrm{H}$ complex as a reagent or an intermediate $\left(\left[\mathrm{RuHCl}\left(\mathrm{H}_{2}\right)\left(\mathrm{PR}_{3}\right)_{2}\right]\right.$ or $\left.\left[\mathrm{RuHCl}\left(\mathrm{PR}_{3}\right)_{2}\right]\right) .{ }^{[10]}$ In fact, Snapper et al. have demonstrated that the purification of commercially available Grubbs 2 catalyst completely suppressed the isomerisation reaction. ${ }^{[11]}$

Nevertheless, it appears that in most cases, the isomerisation process is due to the degradation of the metathesis catalyst itself. Several groups have tried to isolate the putative $[\mathrm{Ru}]-\mathrm{H}$ species but it seems that various complexes are involved. For example, $\mathbf{3}$ and $\mathbf{4}$ have been isolated from the corresponding Grubbs catalysts (Scheme 2). ${ }^{[12]}$ 


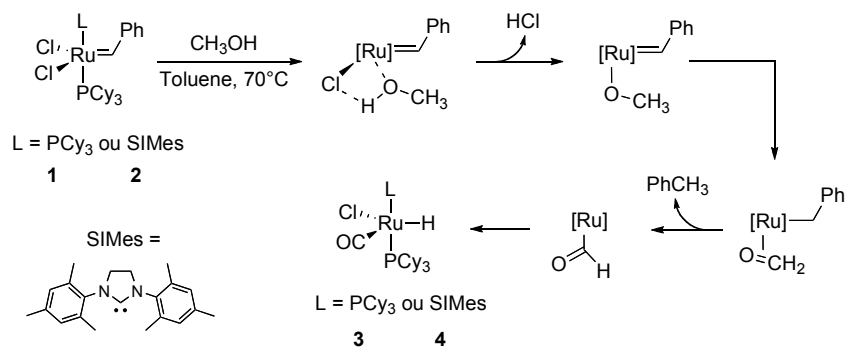

Scheme 2. Dinger and Mol mechanism for Grubbs catalysts decomposition.

The amazing binuclear complex $\mathbf{6}$ has been reported by Grubbs et al. This compound is obtained after thermal decomposition of $\mathbf{5}$ (Scheme 3) ${ }^{[13]}$ It has to be noted that 3, 4 and $\mathbf{6}$ have been shown to be efficient isomerisation catalysts.

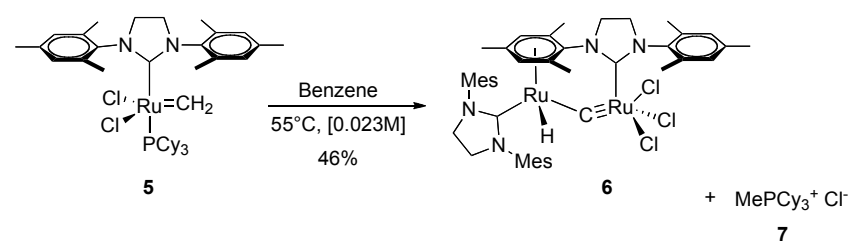

Scheme 3. Example of isolated Ruthenium-hydride complex.

To prevent the isomerisation process, it is mandatory to inhibit the formation of the ruthenium hydride species and/or to eliminate the $[\mathrm{Ru}]-\mathrm{H}$ present in solution. Since the formation of $[\mathrm{Ru}]-\mathrm{H}$ complexes can follow several pathways, it is easier to quench these undesired catalysts rather than bock their formation. To suppress the isomerisation activity, several additives, such as $\mathrm{OPCy}_{3}$, benzoquinones, phenylphosphoric acids or $\mathrm{SnX}_{2}$ derivatives have been successfully employed. ${ }^{[14]}$ It has also been reported that the nature of the solvent can have a significative influence on the metathesis/isomerisation ratio. Indeed, J. Prunet et al., during their studies towards the synthesis of Taxol, have observed that ethereal and aromatic solvents favor isomerisation while the non-polar and non-coordinating dichloroethane can greatly enhance the metathesis/isomerisation ratio. ${ }^{[14 a]}$

\section{Results and Discussion}

We have recently been engaged in the study of a new and efficient approach for the construction of angular triquinane structures, such as Pentalenene (8). Our retrosynthetic analysis is depicted in Scheme 4. It involves, as a key step, a transannular cyclisation of $\mathbf{1 1}$, by intramolecular enolate opening of the $\beta$-epoxide, leading to the diastereoselective formation of 10. Subsequent functional group interconversions will then deliver Pentalenene. The key $\beta$-epoxide 11 would find its origin in the corresponding alkene 12 which could be accessed by a RCM of the precursor 13. This ketone can be assembled by the condensation of the silyl enol ether 15 with the functionalised orthoester 14, according to a methodology we have already described previously. ${ }^{[15]}$

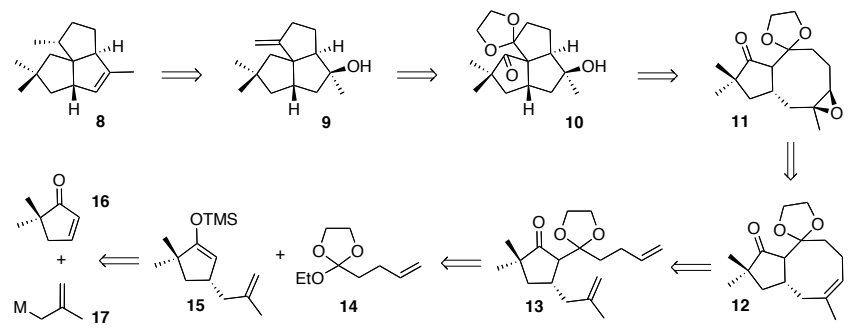

Scheme 4. Retrosynthetic approach to Pentalenene.

To test this approach, the simple model $\mathbf{2 3}$ was initially aimed for (Scheme 5). It was anticipated that this bicyclic ketone would be easily obtained, in three steps, from cyclopentenone 18. Thus, addition of the allyl Grignard reagent 19 on $\mathbf{1 8}$, in the presence of $\mathrm{CuBr}$, generated the silyl enol ether $\mathbf{2 0}$ after treatment of the in-situ generated enolate with TMSCl. Adduct $\mathbf{2 2}$ was next produced as a single diastereoisomer by the condensation of silyl enol ether $\mathbf{2 0}$ with the orthoester 21, under catalysis by zinc chloride. Finally, treatment of 22 by Grubbs 1 catalyst (10 mol-\%) afforded 23 in $70 \%$ yield, after 3 days in DCM, at room temperature.

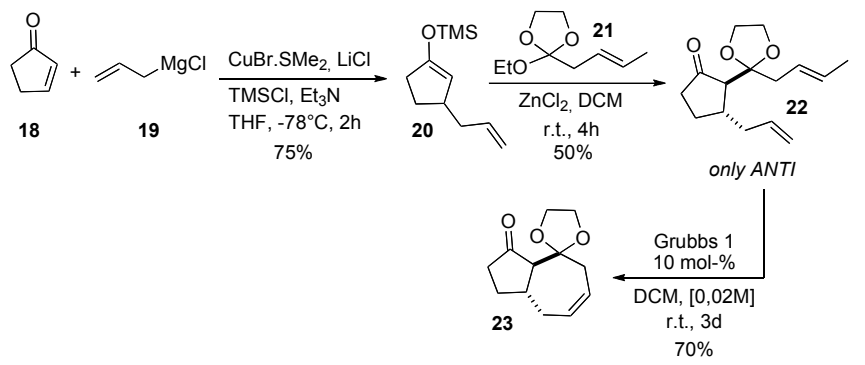

Scheme 5. Synthesis of model compound 23.

Encouraged by the results obtained in the formation of this 7 membered ring, we decided to study the construction of the bicyclo[3.6.0] undecene system needed for the assembly of the triquinanes. The bis-olefinic precursors, 24 and 26, were efficiently assembled by our orthoester condensation method. To our delight, bicyclic adduct 25 was obtained in a reasonable yield of $52 \%$ by the action of Grubbs 1 catalyst, during 5 days, in DCM, at room temperature. Surprisingly, the corresponding isomer 27 was obtained in only $7 \%$ yield when the precursor $\mathbf{2 6}$ was submitted to the same conditions. The yield was slightly improved by performing the reaction in refluxing $\mathrm{CH}_{2} \mathrm{Cl}_{2}$ (Scheme 6).
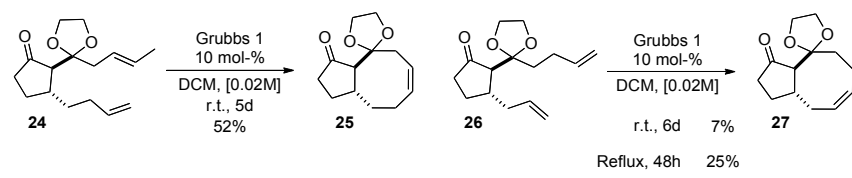

Scheme 6. RCM of bisolefinic precursors $\mathbf{2 4}$ and $\mathbf{2 6}$.

In order to improve the yield and reduce the reaction time, the second generation Grubbs catalyst, which presents an improved 
stability and reactivity was employed. ${ }^{[16]}$ Surprisingly, after 20 hours of reaction in refluxing benzene, a mixture of two compounds was obtained in a 1.1:1 ratio. These proved to be the desired bicycle 27 and the ring-contracted analogue 28 (Scheme 7).

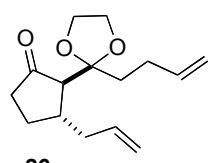

26

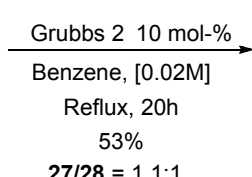

$\mathbf{2 7 / 2 8}=1.1: 1$

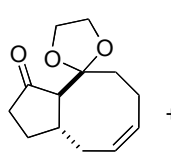

27

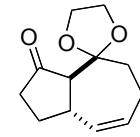

28
Scheme 7. Grubbs 2 catalysed RCM of $\mathbf{2 6}$

The structure of adduct $\mathbf{2 8}$ suggests that the open precursor 26 undergoes a competitive isomerisation of one of the two alkenes The position of the alkene in bicycle $\mathbf{2 8}$ indicates that the allylic substituent has undergone double-bond migration. This observation can be rationalised by the mechanism proposed in Scheme 8 . Starting from 26, direct RCM generates the desired adduct 27 . However, during this process, a competitive isomerisation of one of the two olefins is also observed. Migration of the allylic double bond, followed by RCM, gives access to compound $\mathbf{2 8}$. Considering that $\mathbf{2 3}$ has not been isolated in this transformation, it appears that the isomerisation occurs preferentially at the allylic position. The almost 1:1 ratio of $\mathbf{2 7}$ and $\mathbf{2 8}$ indicates that the isomerisation and the eight-membered ring closure proceed with similar rates $\left(k_{\mathrm{met}} \approx k_{\text {iso } 1}\right)$. The absence of $\mathbf{2 3}$ shows that $k_{\text {isol }}>k_{\text {iso2 }}$ (since $k_{\mathrm{met} 1}$ should be similar to $k_{\mathrm{met} 2}$ ).
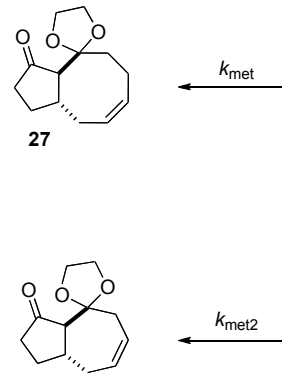

23

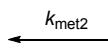

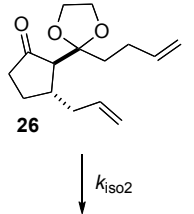

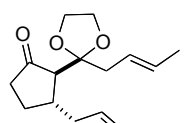

22
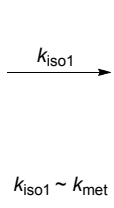
$k_{\text {iso1 }}>k_{\text {iso2 }}$
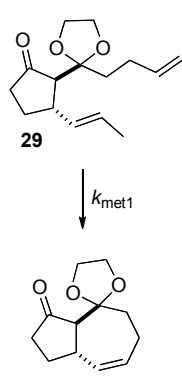

28
Scheme 8. Possible reaction pathways from adduct $\mathbf{2 6}$.

Based upon literature precedents, ${ }^{[14]}$ we have tested various conditions to improve the formation of 27. As shown in Scheme 7, when the reaction was performed in the presence of $10 \mathrm{~mol}-\%$ of Grubbs 2 catalyst, in refluxing benzene, bicycles $\mathbf{2 7}$ and $\mathbf{2 8}$ were isolated in a $\sim 1: 1$ ratio and in $53 \%$ yield (Table 1, entry 1). The yield can be slightly improved in the presence of a lower amount of catalyst (entry 2). However, the ratio $\mathbf{2 7 / 2 8}$ remains unchanged. This observation can be rationalised by considering that metalcarbene dimerisation is a common deactivation pathway for Grubbs catalysts. ${ }^{[17]}$ Replacement of benzene by 1,2dichloroethane (DCE) leads to a slight improvement in the $\mathbf{2 7 / 2 8}$ ratio (entry 3). The concomitant use of Grubbs 2 catalyst and tricyclohexylphosphine oxide (5 mol-\%) didn't enhance the $\mathbf{2 7 / 2 8}$ ratio but lowered the overall yield (entry 4). In stark contrast, employing 1,4-benzoquinone as a sacrificial quencher for the ruthenium hydride species, led to a remarkable enhancement of the 27/28 ratio and a $>20: 1$ mixture of these two bicycles was obtained in a reasonable yield of $57 \%$ (entry 5). Finally, the desired compound $\mathbf{2 7}$ can also be produced in a 15:1 ratio when alkene $\mathbf{2 6}$ was cyclised by adding Grubbs 1 catalyst portionwise to a solution of the substrate in DCE (entry 6). This result highlights the lower propensity of Grubbs 1 catalyst to generate a $[\mathrm{Ru}]-\mathrm{H}$ species as compared to its second-generation counterpart.
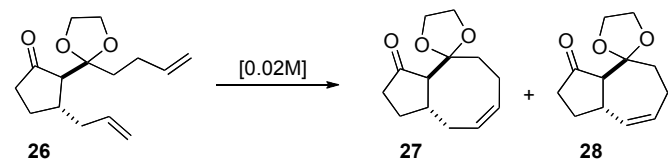

\begin{tabular}{|c|c|c|c|c|c|c|c|c|}
\hline \multirow{2}{*}{$\frac{\text { Entry }}{1}$} & \multicolumn{2}{|c|}{ Catalyst } & \multirow{2}{*}{$\begin{array}{c}\text { Additive } \\
-\end{array}$} & \multirow{2}{*}{$\begin{array}{l}\text { Solvent } \\
\text { Benzene }\end{array}$} & \multirow{2}{*}{$\begin{array}{l}\text { Temp. } \\
\text { Reflux }\end{array}$} & \multirow{2}{*}{$\frac{\text { Time }}{20 \mathrm{~h}}$} & \multirow{2}{*}{$\begin{array}{r}\text { Yield } \\
53 \%\end{array}$} & \multirow{2}{*}{$\frac{27 / 28}{1.1: 1}$} \\
\hline & Grubbs 2 & $10 \mathrm{~mol}-\%$ & & & & & & \\
\hline 2 & Grubbs 2 & $3 \mathrm{~mol}-\%$ & - & Benzene & Reflux & $4 \mathrm{~h}$ & $62 \%$ & $1: 1$ \\
\hline 3 & Grubbs 2 & $3 \mathrm{~mol}-\%$ & - & DCE & Reflux & $24 \mathrm{~h}$ & $49 \%$ & $1.4: 1$ \\
\hline 4 & Grubbs 2 & $3 \mathrm{~mol}-\%$ & $\begin{array}{l}\mathrm{O}=\mathrm{PCy}_{3} \\
5 \mathrm{~mol}^{-} \%\end{array}$ & DCE & Reflux & $24 \mathrm{~h}$ & $30 \%$ & 1.4:1 \\
\hline 5 & Grubbs 2 & $3 \mathrm{~mol}-\%$ & $5 \mathrm{~mol}^{-} \%$ & DCE & Reflux & $24 \mathrm{~h}$ & $57 \%$ & $>20: 1$ \\
\hline 6 & Grubbs 1 & $\begin{array}{l}2 \times 5 \mathrm{~mol}^{-} \\
+2.5 \mathrm{~mol}-\end{array}$ & $\begin{array}{ll}-\% & - \\
-\% & \end{array}$ & DCE & Reflux & $72 \mathrm{~h}$ & $51 \%$ & $15: 1$ \\
\hline
\end{tabular}

Table 1. Products distribution from the RCM of adduct 26.

With these results in hand, we next attempted to assemble a useful intermediate for the synthesis of Pentalenene. One of the simplest modifications involved the introduction of one of the four methyl groups present in the natural product. To our surprise, treatement of 30 with Grubbs 2 catalyst in refluxing benzene leads only to the compound $\mathbf{3 2}$ in a good yield of 70\% (Table 2, entries 1 and 2). This time, the seven membered ring formed during the RCM step results from the isomerisation of the terminal double bond. The use of benzoquinone in DCE improved slightly the ratio, affording a 1:1.25 mixture of the desired product $\mathbf{3 1}$ and its ring-contracted counterpart 32 (entry 3). Unfortunatly, we were unable to separate them by silica gel chromatography (even impregnated with silver nitrate) or by HPLC.
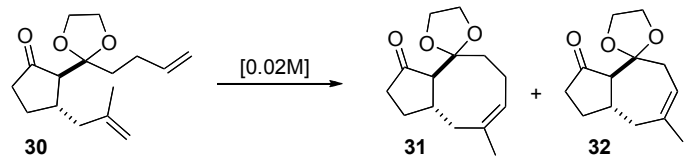

\begin{tabular}{|c|c|c|c|c|c|c|c|c|}
\hline Entry & Catal & yst & Additive & Solvent & Temp. & Time & Yield & Produ \\
\hline 1 & Grubbs 2 & $\begin{aligned} & 3 \mathrm{~mol}-\% \\
+ & 1.5 \mathrm{~mol}-\%\end{aligned}$ & $\%$ & Benzene & Reflux & $20 \mathrm{~h}$ & $67 \%$ & 32 \\
\hline 2 & Grubbs 2 & $3 \mathrm{~mol}-\%$ & - & Benzene & Reflux & $3 d$ & $70 \%$ & 32 \\
\hline 3 & Grubbs 2 & $\begin{array}{c}2 \mathrm{x} \\
5 \mathrm{~mol}-\%\end{array}$ & $2 \times 10 \mathrm{~m}$ & DCE & Reflux & $24 \mathrm{~h}$ & $67 \%$ & $\begin{aligned} & \mathbf{3 2 / 3 1} \\
= & 1.25: 1\end{aligned}$ \\
\hline
\end{tabular}

Table 2. Products distribution from the RCM of adduct 30. 
The behaviour of $\mathbf{2 1}$ and $\mathbf{3 0}$ gives interesting insights on the action of the isomerisation catalyst. Indeed, adding a small methyl substituent is enough to completely inhibit the direct metathesis reaction (Table 2, entries 1 and 2) and to direct the isomerisation on the upper side-chain. These observations indicate that, like the metathesis catalysts, the species responsible for the alkene isomerisation are very sensitive to the steric hindrance around the olefin.

Scheme 9 summarises these transformations. Hence, treatment of $\mathbf{2 6}$ $(\mathrm{R}=\mathrm{H})$, with Grubbs 2 catalyst, in the absence of benzoquinone, produces a nearly 1:1 mixture of $\mathbf{2 7 / 2 8}$, meaning that the rate of metathesis is similar to the rate of isomerisation $\left(k_{\mathrm{met}} \sim k_{\mathrm{isol}}\right)$. On the other hand, if $\mathrm{R}=\mathrm{Me}$, the eight membered ring closure is dramatically slowed down and competitive isomerisation takes place $\left(k_{\text {iso2 }}>k_{\text {met }}\right)$, leading only to 32 . The exclusive formation of 32, implies that the double bond migration proceeds exclusively on the upper side-chain to furnish transiently $\mathbf{3 3}$. It is noteworthy that in the case of 26, no generation of $\mathbf{2 2}$ (and hence, 23) is observed, whilst $\mathbf{3 0}$ affords none of the isomerised $\mathbf{3 4}$. Consequently, no $\mathbf{2 8}$ is produced. The origin of this selectivity will be discussed latter on.

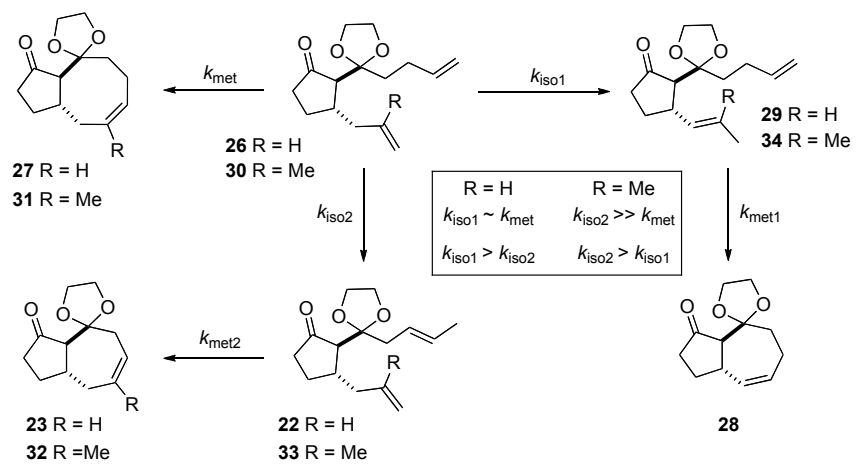

Scheme 9. Reaction pathways comparison between adduct $\mathbf{2 6}$ and $\mathbf{3 0 .}$

Knowing that monosubstituted olefins are preferentially isomerised, and since all the ring-contracted products isolated thus far result from the migration of the olefin by one carbon, we envisioned that diene 35 would be the perfect precursor for the assembly of $\mathbf{3 1}$. Indeed, internalisation of the terminal alkene, followed by ringclosing metathesis, should deliver exclusively 31. Unfortunately, this proved not to be the case and the cyclisation of $\mathbf{3 5}$ in the presence of Grubbs 2 catalyst, in refluxing benzene, only afforded the previously isolated bicycle 32 in 65\% yield (Scheme 10).
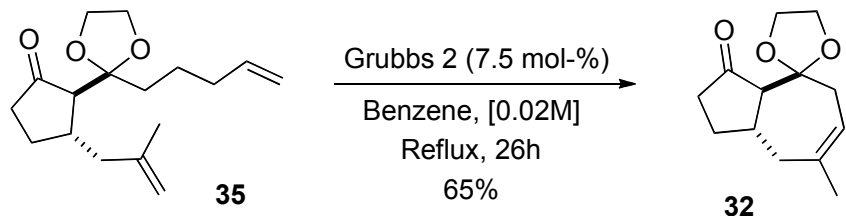

Scheme 10. RCM of the one carbon homologue 35
This result implies that the isomerisation catalyst can slide along the alkyl chain of $\mathbf{3 5}$, leading to repeated migration of the C-C double bond. The exclusive generation of 32 indicates that the isomerisation of $\mathbf{3 5}$ into $\mathbf{3 6}$ and $\mathbf{3 7}$ is much faster than the corresponding ring-closure to afford either the nine- or eightmembered ring adducts $\mathbf{3 8}$ and $\mathbf{3 1}$ respectively (Scheme 11).

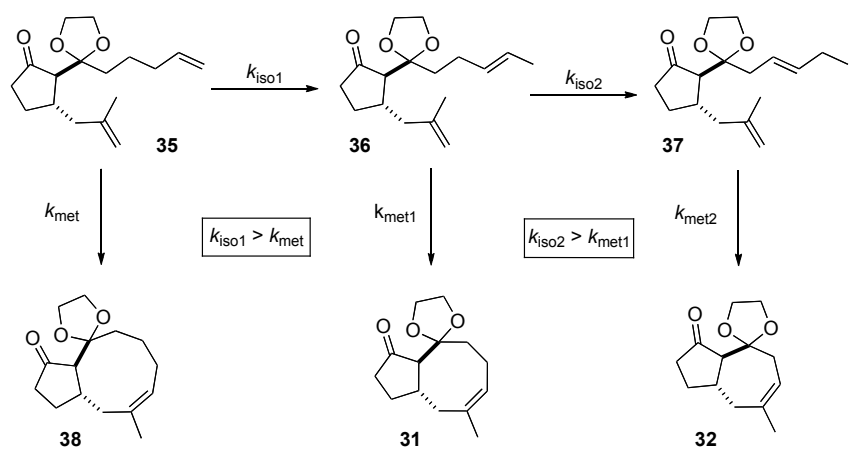

Scheme 11. Possible reaction pathways from adduct 35.

In order to obtain a more precise view on the competition between metathesis and isomerisation, and between the isomerisation of the two side-chains, it was decided to test the substrate 39, possessing two terminal olefins experiencing a similar steric environment. This means that, at the onset of the reaction, both alkenes are equally prone to be complexed by the catalyst and that the structure of the final product(s) will be dictated by the preference for isomerisation vs metathesis. In the event, treatment of $\mathbf{3 9}$ by Grubbs 2 catalyst, in the presence of $10 \mathrm{~mol}-\%$ of $1,4-$ benzoquinone in DCE, afforded $27 \%$ of bicycle $\mathbf{2 5}$ and $2.4 \%$ of $\mathbf{2 8}$ (Scheme 12).
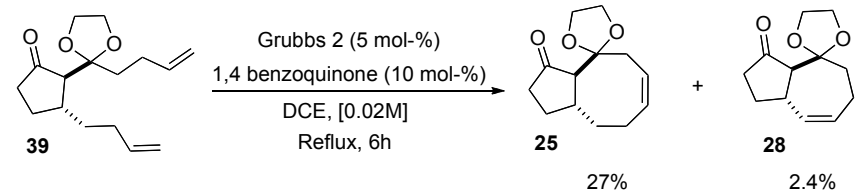

Scheme 12. Grubbs 2 catalysed RCM of adduct 39

A summary of the various processes that can eventually occur during this reaction is presented in Scheme 13. The starting material 39 can follow three different reaction pathways: (1) an RCM leading to the cyclononene derivative 40, (2) the isomerisation of the upper side-chain affording 24 and (3) alkene migration from the lower side-chain generating 41. As expected, the formation of the 9-membered ring was not observed. The product distribution clearly indicates that the reaction sequence furnishing $\mathbf{2 5}$ from $\mathbf{3 9}$, and transiting through $\mathbf{2 4}$, is far more efficient than the one affording 28 by isomerisation of $\mathbf{3 9}$ into $\mathbf{4 1}$ and $\mathbf{4 2}$. This seems to indicate a preferential coordination of the catalyst to the upper chain olefin $\left(k_{\text {iso } 3}>k_{\text {iso } 1}\right)$. At this stage, the RCM of $\mathbf{2 4}$ should be faster than its isomerisation into $\mathbf{4 3}$ since compound $\mathbf{2 3}$ is not observed $\left(k_{\text {met3 }}>k_{\text {iso4 }}\right)$. The absence of $\mathbf{2 3}$ is particularly 
interesting, considering that it could also be formed by isomerisation/RCM of 41. These results suggest that the isomerisation catalyst slides along the alkyl chain without dissociating from the substrate, until it meets a sterically hindering obstacle $\left(k_{\text {iso } 2}>k_{\text {iso5 }}\right)$, at which stage, complete isomerisation is observed. Hence, 39 should isomerise directly to $\mathbf{4 2}$ without formation of free 41. This hypothesis is strengthened by the fact that $\mathbf{2 7}$ and $\mathbf{2 3}$ are not observed.

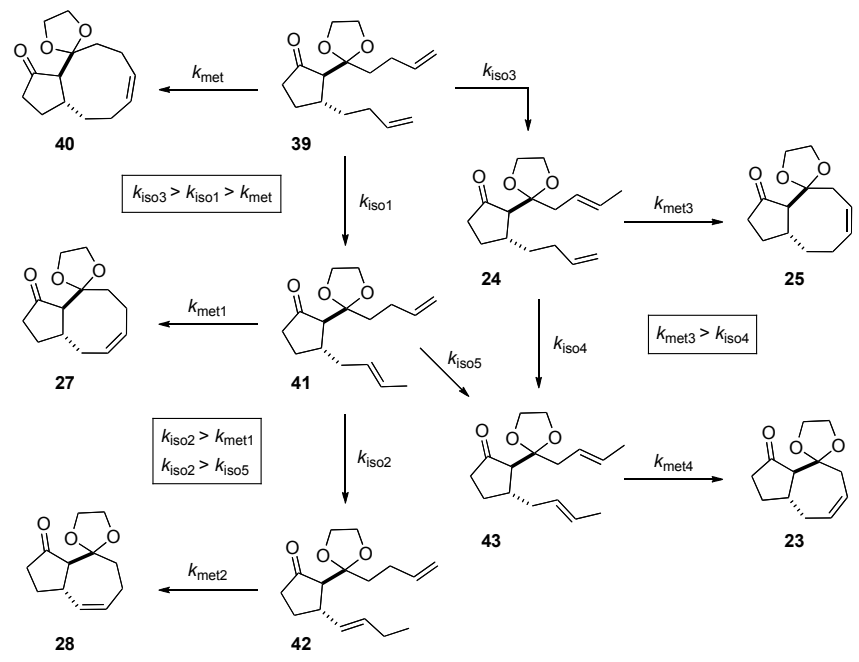

Scheme 13. Possible reaction pathways from adduct 39.

\section{Formation of the isomerisation catalyst.}

All these examples indicate that the product distribution depends upon the relative rate of cyclisation and isomerisation. In fact, the cyclisation rate decreases with increasing ring size and olefin substitution. This phenomenon is strengthened by long reaction times, which favor catalyst decomposition. Unfortunately, the $[\mathrm{Ru}]-\mathrm{H}$ complexes are possible products of this degradation that will increase the isomerisation reaction at the expense of the cyclisation. Indeed, in the formation of $\mathbf{2 7}$ and $\mathbf{2 8}$ from diene $\mathbf{2 6}$, the ratio $27 / 28$ will be determined by the ratio $V_{\text {met }} / V_{\text {iso }}$ depending itself on the corresponding rate constant of the reaction $k_{\text {met }}$ and $k_{\text {iso }}$ (Scheme 14). However, these rate constants are apparent constants since they depend upon the catalytic species concentrations (equations (1) and (2)). The product ratio can then be expressed by the equation (3). Consequently, the decomposition of the catalyst will result in a dual effect since the decrease in $[\mathrm{Ru}]=\mathrm{CH}_{2}$ concentration will not only lower the rate of cyclisation but also increase the amount of $[\mathrm{Ru}]-\mathrm{H}$, culminating in a higher rate of isomerisation.

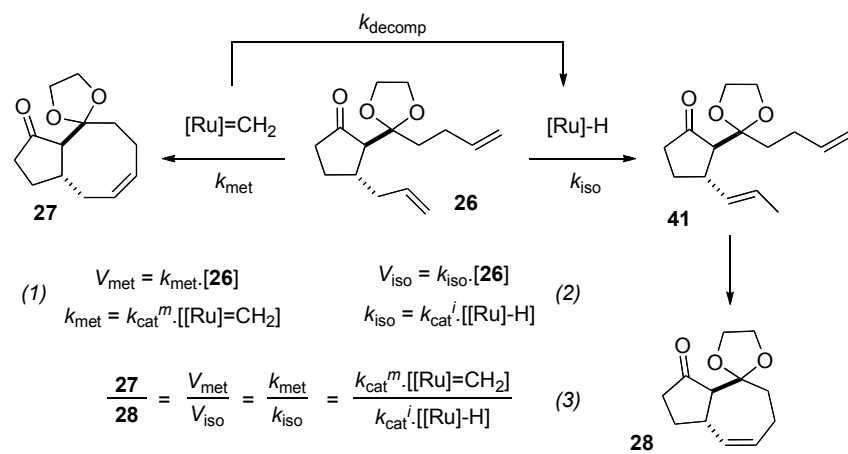

Scheme 14. Isomerisation/metathesis rate comparison of adduct $\mathbf{2 6}$

Previous studies on the formation of the catalytic species responsible for the isomerisation have always tackled the problem through the investigation of the decomposition of the metathesis catalyst. However, our substrates react particularly slowly and the isomerisation is extremely important as compared with reactants of similar ring size ${ }^{[6]}$ It is therefore plausible that a structural feature of our starting material might also be responsible for this enhanced isomerisation. ${ }^{[18]}$ We believe that the spatial proximity between the dioxolane and the upper side-chain double bond might be the culprit and that this functional group might be responsible, to a certain extent, for the reaction's sluggishness. Coordination of the ruthenium complex to one of the ketal oxygen lone pairs, could result in catalyst sequestration and/or decomposition. ${ }^{[19]}$ Indeed, during an attempt to build macrolactones by ring closing metathesis, A. Fürstner et al. have observed that the rate of reaction strongly depended upon the distance between the double bond and the ester group. The lowest rates were observed if this distance enabled the formation of a 5- or 6-membered ring bidentate complex. ${ }^{[19 a]}$ The postulated mechanism presented in Scheme $\mathbf{1 5}$ takes this observation into account. Thus, intermediate $\mathbf{A}$, which could lead to bicycle 26, could be in equilibrium with the complexed form $\mathbf{B}$. The 6-membered ring bidentate coordination should favour form B over $\mathbf{A}$ and act as a sink for the catalyst. Isomerisation will provide $\mathbf{C}$ which will slowly close to $\mathbf{2 8}$. In addition, it is possible that the complexed form $\mathbf{B}$ might be an intermediate in the decomposition pathway leading to the ruthenium hydride catalyst. Finally, in the presence of $[\mathrm{Ru}]-\mathrm{H}$, compound $\mathbf{2 6}$ could give rise directly to isomerized product $\mathbf{D}$ (transiting by $\mathbf{4 1}$ ). 


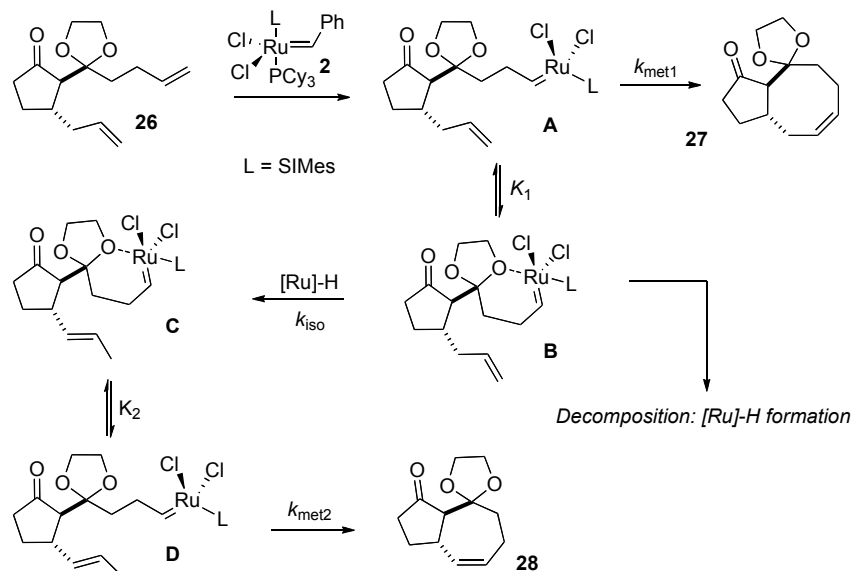

Scheme 15. Possible substrate induced catalyst deactivation mechanism

Based upon the mechanism proposed by Dinger and Mol, ${ }^{[12]}$ a plausible mechanism of decomposition, taking into account the particular structure of our substrate, is depicted in Scheme 16. The dioxolane present in $\mathbf{A}$ could be opened to generate the cyclic oxonium cation $\mathbf{B}$. This species can be trapped by a chloride ion to afford intermediate C. A hydride transfer between the alcool and the metal-carbene then affords $\mathbf{D}$, which could subsequently decompose into complexes $\mathbf{F}$ and $\mathbf{H}$ respectively. Finally, the ruthenium hydride derivative I can be obtained by loss of CO.

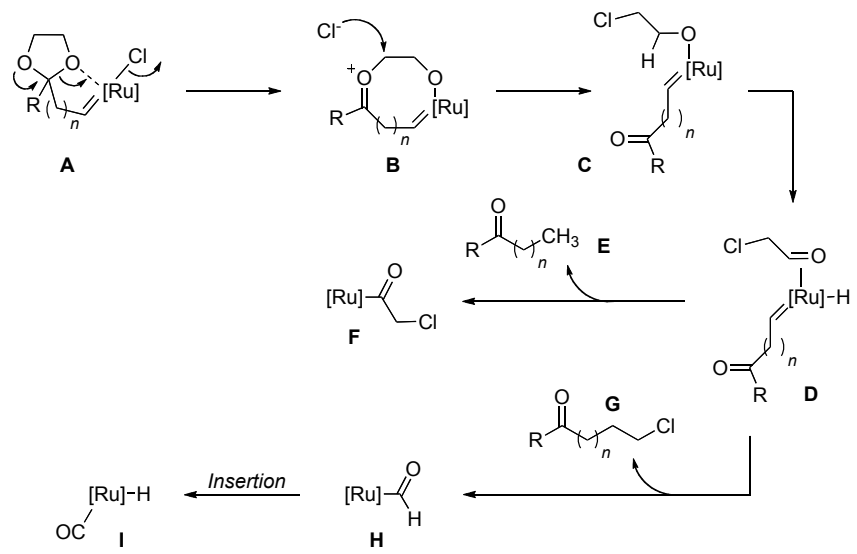

Scheme 16. Proposed mechanism for the decomposition of the catalyst.

It is interesting to note that, once generated, the ruthenium hydride species should attach itself to the ketal oxygens much faster than the RCM catalyst, therefore resulting in rapid isomerisation; steric and chelation control providing the end-point for the alkene migration.

Based upon these observations the functionalised tricyclic core of Pentalenene could be rapidly assembled. Initially, the compound 26 was converted in bicycle $\mathbf{2 7}$ by RCM using Grubbs 2 catalyst and 5 mol- $\%$ of benzoquinone in refluxing DCE (Scheme 17). Adduct 27 was then treated by mCPBA to furnish the corresponding epoxide as a mixture of the two diastereoisomers 44 and 45. The almost 1:1 ratio indicated a total lack of facial selectivity. Since only $\mathbf{4 5}$ possess the proper configuration to cyclise, the two diastereoisomers were separated and 45 was reacted with sodium hydride to afford the triquinane 46 in $60 \%$ yield. The highly functionalised angular triquinane $\mathbf{2 8}$ can thus be obtained in 5 steps from cyclopentenone and in 9\% overall yield This intermediate possesses all the functionalities at the proper positions to build Pentalenene.

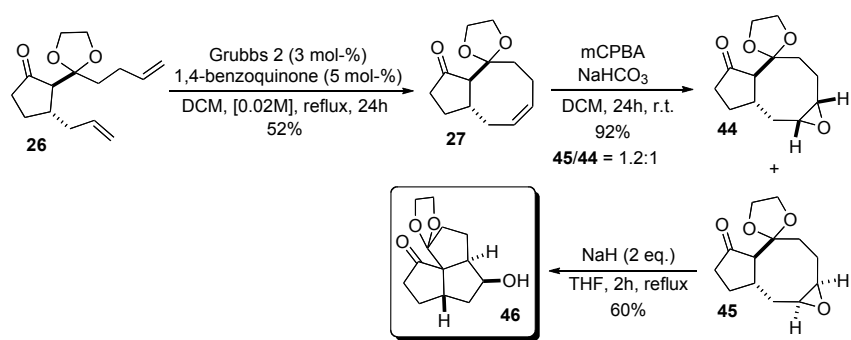

Scheme 17. Synthesis of a triquinane structure.

\section{Conclusions}

In summary, we have shown that the isomerisation reaction occurs when the metathesis reaction is rather slow. In this case, there is a competition between the two reactions. As Ru hydride species, believed to catalyse the isomerisation reaction, are formed by decomposition of the metathesis catalyst, a prolonged reaction time favors the isomerisation process. The behaviour of the isomerisation catalyst has been investigated. Like its metathesis counterpart, the isomerisation catalyst is sensitive to steric hindrance. Hence, isomerisation will preferentially take place on the less substituted olefin. Moreover, it has been shown that this catalytic species performs the isomerisation by sliding along the carbon chain until a sterically hindered position induces its decomplexation. The efficiency of the isomerisation process, not only depends upon the catalyst employed, but also on the structure of the substrate. In fact, the formation of a favourable complex between the dioxolane moiety and the Ru carbene is thought to act as a sink for the metathesis catalyst and to lead the way to decomposition and $\mathrm{Ru}-\mathrm{H}$ formation. Finally, we have illustrated the power of this approach by the rapid assembly of an intermediate for the total synthesis of Pentalenene.

\section{Experimental Section}

NMR spectra were recorded on BRUKER AC-300 Avance II $\left({ }^{1} \mathrm{H}\right.$ : 300 MHz and $\left.{ }^{13} \mathrm{C}: 75 \mathrm{MHz}\right)$ or on a BRUKER AM-500 $\left({ }^{1} \mathrm{H}: 500 \mathrm{MHz}\right.$ and ${ }^{13} \mathrm{C}$ : $125 \mathrm{MHz}$ ). All spectra were internally referenced to residual protio solvent signals. Detailed NMR assignments were done through analysis of 1D (DEPT 135 or DEPTQ) and 2D (COSY, HMQC, HMBC) spectra. Lowresolution mass spectra were recorded using VARIAN MATT-44 and FINNIGAN MAT-TSQ 70 spectrometers with chemical ionisation (CI, 100 $\mathrm{eV}$, ionisation gas: isobutane), atmospheric pressure chemical ionisation (APCI, $100 \mathrm{eV}$, ionisation gas: isobutane) and electrospray ionisation (ESI). 
High resolution mass spectra were performed on THERMO FINNIGAN MAT900XP (CI and EI) and on WATERS LCT Premier XE (ESI). The measured mass was calculated from an average of ten accurate mass calculations. Infrared (IR) spectra were recorded on a SHIMADZU FTIR$8400 \mathrm{~S}$ spectrometer and are reported in terms of frequency of absorption $\left(\mathrm{cm}^{-1}\right)$. The samples were analysed as thin films deposited on a $\mathrm{ZnSe}$ cristal. Peaks intensities are described as follows: $\mathrm{s}=$ strong, $\mathrm{m}=$ medium, $\mathrm{w}=$ weak, $b=$ broad. Solvents were of technical grade and distilled prior to use. Diethylether and THF were distilled over sodium/benzophenone. Dichloromethane, dichloroethane, toluene, benzene and triethylamine were distilled over $\mathrm{CaH}_{2}$. Degassed solvents were prepared on small volume (< $50 \mathrm{~mL}$ ) by three "freeze/pump/thaw" cycles. On a larger volume, solvents were degassed by bubbling argon for 30 to 60 minutes. All commercially available compounds (Acros, Aldrich, Fluka and Lancaster) were used as received unless otherwise stated. All reactions were carried out under an atmosphere of argon, in flame-dried apparatus and with magnetic stirring. Thin-layer chromatographies (TLC) were performed on TLC aluminium sheets coated with Silica gel 60 F254 (Merck). The plates were visualised using ultra-violet light $(256 \mathrm{~nm})$ and developed using $\mathrm{KMnO} 4$ and/or phosphomolybdic acid. Flash chromatographies were performed using Merck Silica Gel 60 (230-400 mesh) under pressure with the stated solvents.

\section{(Z)-3a,5,8,8a-tetrahydro-1H-spiro[azulene-4,2'-[1,3]dioxolan]-3(2H)-} one (23): Degassed DCM (25 mL), diene $22(90 \mathrm{mg}, 0.360 \mathrm{mmol}, 1 \mathrm{eq}$ ) and Grubbs 1 catalyst ( $31 \mathrm{mg}, 0.038 \mathrm{mmol}, 0.105$ eq.) are introduced in a three necked flask. The resulting solution is stirred for 3 days at room temperature. After this period, the mixture is concentrated under vacuum and a black residue is recovered. Purification (silica gel column, Hexane $\left./ \mathrm{Et}_{2} \mathrm{O}=6 / 4, \mathrm{R}_{\mathrm{f}}=0.22\right)$ affords $55 \mathrm{mg}(0.264 \mathrm{mmol})$ of a white solid Yield $=73 \%$. ${ }^{1} \mathrm{H}$ NMR $\left(300 \mathrm{MHz}, \mathrm{CDCl}_{3}\right): \delta(\mathrm{ppm})=5.77\left(\mathrm{dt},{ }^{3} \mathrm{~J}_{\text {cis }}=11.0\right.$ $\left.\mathrm{Hz},{ }^{3} \mathrm{~J}=5.1 \mathrm{~Hz}, 1 \mathrm{H},-\mathrm{CO}_{2}-\mathrm{CH}_{2}-\mathrm{CH}=\right), 5.57-5.51\left(\mathrm{~m}, 1 \mathrm{H},-\mathrm{CH}-\mathrm{CH}_{2}-\mathrm{CH}=\right)$ 4.25-4.21 (m, $\left.1 \mathrm{H},-\mathrm{OCH}_{2}-\mathrm{CH}_{2} \mathrm{O}-\right)$, 3.96-3.85 (m, 3H, $\left.-\mathrm{OCH}_{2}-\mathrm{CH}_{2} \mathrm{O}-\right)$, 2.62$2.56\left(\mathrm{~m}, 1 \mathrm{H},-\mathrm{CH}-\mathrm{CH}_{2}-\mathrm{CH}=\right), 2.54\left(\mathrm{dddd},{ }^{2} \mathrm{~J}=15.2 \mathrm{~Hz},{ }^{3} \mathrm{~J}=6.7 \mathrm{~Hz},{ }^{4} \mathrm{~J}=2.7\right.$ $\left.\mathrm{Hz},{ }^{4} \mathrm{~J}=1.4 \mathrm{~Hz}, 1 \mathrm{H},-\mathrm{CO}_{2}-\mathrm{CH}_{2}-\mathrm{CH}=\right), 2.47-2.39(\mathrm{~m}, 2 \mathrm{H},-\mathrm{CH}-\mathrm{CH}-), 2.33-$ $2.14\left(\mathrm{~m}, 3 \mathrm{H},-\mathrm{CH}_{2}-\mathrm{CO}-\mathrm{CH}-\mathrm{CO}_{2}-\mathrm{CH}_{2}-\mathrm{CH}=\right), 2.13-2.03\left(\mathrm{~m}, 2 \mathrm{H},-\mathrm{CH}_{2}-\mathrm{CH}\right.$ $\left.\mathrm{CH}_{2}-\mathrm{CH}=\right), 1.37-1.20\left(\mathrm{~m}, 1 \mathrm{H},-\mathrm{CH}_{2}-\mathrm{CH}_{2}-\mathrm{CO}-\right) .{ }^{13} \mathrm{C} \quad \mathrm{NMR}(75 \mathrm{MHz}$, $\left.\mathrm{CDCl}_{3}\right): \delta(\mathrm{ppm})=215.4(\mathrm{C}=\mathrm{O}), 131.1\left(-\mathrm{CO}_{2}-\mathrm{CH}_{2}-\mathrm{CH}=\right), 124.2\left(-\mathrm{CH}-\mathrm{CH}_{2}-\right.$ $\mathrm{CH}=), 111.4\left(-\mathrm{CO}_{2}-\right), 66.0$ and $64.8\left(-\mathrm{OCH}_{2}-\mathrm{CH}_{2} \mathrm{O}-\right), 62.0\left(-\mathrm{CO}-\mathrm{CH}-\mathrm{CO}_{2}-\right)$, 39.9 (- $\left.\mathrm{CH}_{2}-\mathrm{CO}-\right), 38.3$ (-CO-CH-CH-), $37.2\left(-\mathrm{CO}_{2}-\mathrm{CH}_{2}-\right), 35.9\left(-\mathrm{CH}-\mathrm{CH}_{2-}\right.$ $\mathrm{CH}=), 28.7\left(-\mathrm{CH}_{2}-\mathrm{CH}_{2}-\mathrm{CO}-\right) . \mathrm{MS}(+\mathrm{APCI}):(\mathrm{m} / \mathrm{z})=209\left(46,[\mathrm{MH}]^{+}\right), 179$ $\left(100,\left[\mathrm{MH}-\mathrm{C}_{2} \mathrm{H}_{6}\right]^{+}\right), 165\left(14,[\mathrm{MH}-\text { acetaldehyde }]^{+}\right)$. IR (film, $\left.\mathrm{cm}^{-1}\right): v=$ $3022 \mathrm{w}, 2957 \mathrm{~m}, 2928 \mathrm{~m}, 2895 \mathrm{~m}, 1741 \mathrm{~s}, 1275 \mathrm{~m}, 1159 \mathrm{~m}, 1138 \mathrm{~m}, 1043$ m, $1020 \mathrm{~m}, 1007 \mathrm{~m}, 949 \mathrm{~m}$. HRMS $(+\mathrm{CI})$ : calcd. for $[\mathrm{MH}]^{+}\left(\mathrm{C}_{12} \mathrm{H}_{17} \mathrm{O}_{3}\right)$ : 209.11777, found: 209.11780

(Z)-3a,5,6,8a-tetrahydro-1H-spiro[azulene-4,2'-[1,3]dioxolan]-3(2H)one (28): Degassed benzene $(50 \mathrm{~mL})$, diene $26(250 \mathrm{mg}, 1.000 \mathrm{mmol}, 1$ eq.) and Grubbs 2 catalyst ( $28 \mathrm{mg}, 0.033 \mathrm{mmol}, 0.033$ eq.) are introduced in a three necked flask. The resulting solution is heated to reflux and stirred for 4 hours. After this period, the mixture is concentrated under vacuum and a black residue is recovered (TLC: $\mathrm{PE} / \mathrm{Et}_{2} \mathrm{O}=1 / 1, \mathrm{R}_{\mathrm{f}}=0.26(\mathbf{2 8}), 0.215$ (27)). Purification (silica gel column, $\left.\mathrm{PE} / \mathrm{Et}_{2} \mathrm{O}=7 / 3\right)$ affords $70 \mathrm{mg}(0.336$ $\mathrm{mmol})$ of 28 and $70 \mathrm{mg}(0.315 \mathrm{mmol})$ of 27 (both as a white solid). Yield = $34 \% .{ }^{1} \mathrm{H}$ NMR $\left(300 \mathrm{MHz}, \mathrm{CDCl}_{3}\right): \delta(\mathrm{ppm})=5.78-5.71\left(\mathrm{~m}, 1 \mathrm{H},-\mathrm{CH}_{2}-\mathrm{CH}=\right)$ $5.66\left(\mathrm{bd},{ }^{3} \mathrm{~J}=10.7 \mathrm{~Hz}, 1 \mathrm{H},-\mathrm{CH}-\mathrm{CH}=\right)$, 4.27-4.18 (m, $1 \mathrm{H},-\mathrm{OCH}_{2}-\mathrm{CH}_{2} \mathrm{O}-$ ), 3.94-3.85 (m, 3H, - $\left.\mathrm{OCH}_{2}-\mathrm{CH}_{2} \mathrm{O}-\right), 3.09-2.94(\mathrm{~m}, 1 \mathrm{H},-\mathrm{CH}-\mathrm{CH}=), 2.45\left(\mathrm{~d},{ }^{3} \mathrm{~J}\right.$ $\left.=12.2 \mathrm{~Hz}, 1 \mathrm{H},-\mathrm{CO}-\mathrm{CH}-\mathrm{CO}_{2}-\right), 2.33-2.07\left(\mathrm{~m}, 5 \mathrm{H},-\mathrm{CO}-\mathrm{CH}_{2}-\mathrm{CH}_{2}-\mathrm{CH}-\right.$ $\left.\mathrm{CH}=\mathrm{CH}-\mathrm{CH}_{2}-\right), 1.94\left(\mathrm{ddd},{ }^{2} \mathrm{~J}=14.0 \mathrm{~Hz},{ }^{3} \mathrm{~J}=10.5 \mathrm{~Hz},{ }^{3} \mathrm{~J}=2.3 \mathrm{~Hz}, 1 \mathrm{H}\right.$, $\left.\mathrm{CO}_{2}-\mathrm{CH}_{2}-\right), 1.67\left(\mathrm{ddd},{ }^{2} \mathrm{~J}=14.2 \mathrm{~Hz},{ }^{3} \mathrm{~J}=7.7 \mathrm{~Hz},{ }^{3} \mathrm{~J}=2.1 \mathrm{~Hz}, 1 \mathrm{H},-\mathrm{CO}_{2}-\mathrm{CH}_{2-}\right.$ ), $1.54-1.38\left(\mathrm{~m}, 1 \mathrm{H},-\mathrm{CO}-\mathrm{CH}_{2}-\mathrm{CH}_{2}-\right) .{ }^{13} \mathrm{C} \mathrm{NMR}\left(75 \mathrm{MHz}, \mathrm{CDCl}_{3}\right): \delta(\mathrm{ppm})$ $=215.5(\mathrm{C}=\mathrm{O}), 133.2(-\mathrm{CH}-\mathrm{CH}=), 131.0\left(-\mathrm{CH}_{2}-\mathrm{CH}=\right), 111.5\left(-\mathrm{CO}_{2}-\right), 66.0$ and $64.8\left(-\mathrm{OCH}_{2}-\mathrm{CH}_{2} \mathrm{O}-\right), 59.9\left(-\mathrm{CO}-\mathrm{CH}-\mathrm{CO}_{2}-\right), 39.9\left(-\mathrm{CO}-\mathrm{CH}_{2}-\right), 39.1$ $\mathrm{CH}-\mathrm{CH}=), 36.9\left(-\mathrm{CO}_{2}-\mathrm{CH}_{2}-\right), 27.6\left(-\mathrm{CO}-\mathrm{CH}_{2}-\mathrm{CH}_{2}-\right), 23.9\left(-\mathrm{CH}_{2}-\mathrm{CH}=\right) . \mathrm{MS}$ $(+\mathrm{ESI}):(\mathrm{m} / \mathrm{z})=231\left(52,[\mathrm{M}+\mathrm{Na}]^{+}\right), 209\left(26,[\mathrm{MH}]^{+}\right), 165(26,[\mathrm{MH}-$ acetaldehyde $\left.]^{+}\right)$. MS (+APCI): $(\mathrm{m} / z)=209\left(74,[\mathrm{MH}]^{+}\right), 179(100,[\mathrm{MH}-$ $\left.\left.\mathrm{C}_{2} \mathrm{H}_{6}\right]^{+}\right), 191\left(34,\left[\mathrm{MH}-\mathrm{H}_{2} \mathrm{O}\right]^{+}\right), 165\left(60,[\mathrm{MH} \text {-acetaldehyde }]^{+}\right)$. IR (film, cm $\left.{ }^{1}\right): v=2924 \mathrm{~m}, 2852 \mathrm{w}, 1745 \mathrm{~s}, 1458 \mathrm{w}, 1437 \mathrm{w}, 1317 \mathrm{w}, 1277 \mathrm{w}, 1261 \mathrm{w}$, 1217 w, 1196 w, 1151 m, 1089 w, 1036 m, 989 w, 949 w, 914 w, 895 w. HRMS (+EI): calcd. for [M] ${ }^{+}\left(\mathrm{C}_{12} \mathrm{H}_{16} \mathrm{O}_{3}\right): 208.10940$, found: 208.10969 .

\section{(Z)-7-methyl-3a,5,8,8a-tetrahydro-1H-spiro[azulene-4,2'-}

[1,3]dioxolan]-3(2H)-one (32): Degassed benzene $(170 \mathrm{~mL})$, diene 30 (900 $\mathrm{mg}, 3.400 \mathrm{mmol}, 1$ eq.) and Grubbs 2 catalyst $(87 \mathrm{mg}, 0.102 \mathrm{mmol}, 0.03$ eq.) are introduced in a three necked flask. The resulting solution is heated to reflux and stirred for 6 hours. Then, a second portion of Grubbs 2 catalyst is added $(87 \mathrm{mg}, 0.102 \mathrm{mmol}, 0.03$ eq.). The reaction mixture is stirred 3 days. After this period, the mixture is concentrated under vacuum and a black residue is recovered. Purifications (silica gel column, $\mathrm{PE} / \mathrm{Et}_{2} \mathrm{O}$
$=8 / 2$ then horizontal distillation: $\left.170^{\circ} \mathrm{C}, 1 \mathrm{mbar}\right)$ affords $564 \mathrm{mg}(2.53$ mmol) of a colorless liquid. Yield $=75 \%$. ${ }^{1} \mathrm{H}$ NMR $\left(300 \mathrm{MHz}, \mathrm{CDCl}_{3}\right): \delta$ $(\mathrm{ppm})=5.27\left(\mathrm{t},{ }^{3} \mathrm{~J}=6.6 \mathrm{~Hz}, 1 \mathrm{H},-\mathrm{CH}_{2}-\mathrm{CH}=\right), 4.24\left(\mathrm{~m}, 1 \mathrm{H},-\mathrm{OCH}_{2}-\mathrm{CH}_{2} \mathrm{O}-\right)$, 3.93-3.81 (m, 3H, -OCH $\left.\mathrm{H}_{2}-\mathrm{CH}_{2} \mathrm{O}-\right)$, 2.53-1.89 (m, 9H), $1.69\left(\mathrm{~s}, 3 \mathrm{H},-\mathrm{CH}_{3}\right)$, $1.48-1.45\left(\mathrm{~m}, 1 \mathrm{H},-\mathrm{CO}-\mathrm{CH}_{2}-\mathrm{CH}_{2}-\right) .{ }^{13} \mathrm{C} \mathrm{NMR}\left(75 \mathrm{MHz}, \mathrm{CDCl}_{3}\right): \delta(\mathrm{ppm})=$ $215.4(\mathrm{C}=\mathrm{O}), 131.1(=\mathrm{CH}-), 124.2\left(\mathrm{CH}_{3}-\mathrm{C}=\right), 111.4\left(-\mathrm{CO}_{2}-\right), 66.0$ and 64.8 $\left(-\mathrm{OCH}_{2}-\mathrm{CH}_{2} \mathrm{O}-\right)$, 62.1 (-CO-CH-CO $\left.{ }_{2-}^{-}\right), 41.1$ (-CO- $\left.\mathrm{CH}_{2-}\right), 39.8\left(-\mathrm{CO}_{2}-\mathrm{CH}_{2}-\right)$, 38.0 (-CO-CH-CH-), $36.8\left(-\mathrm{CH}_{2}-\mathrm{C}-\mathrm{CH}_{3}\right), 28.9\left(-\mathrm{CO}-\mathrm{CH}_{2}-\mathrm{CH}_{2}-\right), 25.9$ ($\left.\mathrm{CH}_{3}\right)$. MS (+APCI): $(\mathrm{m} / z)=223\left(100,[\mathrm{MH}]^{+}\right), 221\left(42,\left[\mathrm{MH}-\mathrm{H}_{2}\right]^{+}\right), 219(18$, $\left.\left[\mathrm{MH}-2 \mathrm{H}_{2}\right]^{+}\right), 193\left(18,\left[\mathrm{MH}-\mathrm{C}_{2} \mathrm{H}_{6}\right]^{+}\right), 179\left(19,[\mathrm{MH} \text {-acetaldehyde }]^{+}\right), 175(37$, $\left[\mathrm{MH} \text {-acetladehyde-2 } \mathrm{H}_{2}\right]^{+}$). IR (film, $\mathrm{cm}^{-1}$ ): $v=2964 \mathrm{~m}, 2927 \mathrm{~m}, 2893 \mathrm{~m}$, $2876 \mathrm{~m}, 1703 \mathrm{~s}, 1443 \mathrm{bm}, 1275 \mathrm{~s}, 1142 \mathrm{~s}, 1130 \mathrm{~s}, 1040 \mathrm{~s}, 1016 \mathrm{~s}, 951 \mathrm{~s}$ $897 \mathrm{~m}, 854 \mathrm{~m}, 847 \mathrm{~m}$. HRMS $(+\mathrm{CI})$ : calcd for $[\mathrm{MH}]^{+}\left(\mathrm{C}_{13} \mathrm{H}_{19} \mathrm{O}_{3}\right)$ 223.13342, found: 223.13314. Elemental analysis for $\mathrm{C}_{13} \mathrm{H}_{18} \mathrm{O}_{3}(222.28)$ : calcd. C 70.24, H 8.16; found C 68.04, H 7.94

\section{(Z)-1,2,5,8,9,9a-hexahydrospiro[cyclopenta[8] annulene-4,2'-}

[1,3]dioxolan]-3(3aH)-one (25): Degassed DCM (60 mL), diene 24 (300 $\mathrm{mg}, 1.130 \mathrm{mmol}, 1$ eq.) and Grubbs 1 catalyst (93 mg, $0.113 \mathrm{mmol}, 0.1 \mathrm{eq}$.) are introduced in a three necked flask. The resulting solution is stirred for 5 days at room temperature. After this period, the mixture is concentrated under vacuum and a black residue is recovered. Purification (silica gel column, $\mathrm{PE} / \mathrm{Et}_{2} \mathrm{O}=7 / 3$ then horizontal distillation: $170^{\circ} \mathrm{C}, 1 \mathrm{mbar}$ ) affords $130 \mathrm{mg}(0.585 \mathrm{mmol})$ of a white solid. Yield $=52 \%$. ${ }^{1} \mathrm{H}$ NMR $(300 \mathrm{MHz}$, $\left.\mathrm{CDCl}_{3}\right): \delta(\mathrm{ppm})=5.85\left(\mathrm{dt},{ }^{3} \mathrm{~J}=9.8 \mathrm{~Hz},{ }^{3} \mathrm{~J}=7.9 \mathrm{~Hz}, 1 \mathrm{H},-\mathrm{CH}_{2}-\mathrm{CH}_{2}-\mathrm{CH}=\right)$, 5.64 (tdd, $\left.{ }^{3} \mathrm{~J}=10.3 \mathrm{~Hz},{ }^{3} \mathrm{~J}=7.9 \mathrm{~Hz},{ }^{4} \mathrm{~J}=1.5 \mathrm{~Hz}, 1 \mathrm{H},-\mathrm{CO}_{2}-\mathrm{CH}_{2}-\mathrm{CH}=\right)$, 4.15$4.07\left(\mathrm{~m}, 1 \mathrm{H},-\mathrm{OCH}_{2}-\mathrm{CH}_{2} \mathrm{O}-\right), 4.00-3.89\left(\mathrm{~m}, 2 \mathrm{H},-\mathrm{OCH}_{2}-\mathrm{CH}_{2} \mathrm{O}-\right), 3.80-3.72$ $\left(\mathrm{m}, 1 \mathrm{H},-\mathrm{OCH}_{2}-\mathrm{CH}_{2} \mathrm{O}-\right), 2.70\left(\mathrm{dd},{ }^{2} \mathrm{~J}=13.1 \mathrm{~Hz},{ }^{3} \mathrm{~J}_{\text {trans }}=10.4 \mathrm{~Hz}, 1 \mathrm{H},-\mathrm{CO}_{2}-\right.$ $\left.\mathrm{CH}_{2}-\mathrm{CH}=\right), 2.53\left(\mathrm{~d},{ }^{3} \mathrm{~J}=8.9 \mathrm{~Hz}, 1 \mathrm{H},-\mathrm{CO}-\mathrm{CH}-\mathrm{CO}_{2}-\right), 2.48-2.05(\mathrm{~m}, 7 \mathrm{H})$, $1.94\left(\mathrm{ddt},{ }^{2} \mathrm{~J}=13.8 \mathrm{~Hz},{ }^{3} \mathrm{~J}=5.9 \mathrm{~Hz},{ }^{3} \mathrm{~J}=2.3 \mathrm{~Hz}, 1 \mathrm{H},-\mathrm{CH}_{2}-\mathrm{CH}_{2}-\mathrm{CH}=\right)$, $1.35-$ $1.17\left(\mathrm{~m}, 2 \mathrm{H},-\mathrm{CH}_{2}-\mathrm{CH}-\mathrm{CH}_{2}-\mathrm{CH}_{2}-\mathrm{CH}=\right) .{ }^{13} \mathrm{C} \mathrm{NMR}\left(75 \mathrm{MHz}, \mathrm{CDCl}_{3}\right)$ : $\delta$ $(\mathrm{ppm})=217.8(\mathrm{C}=\mathrm{O}), 132.7(-\mathrm{CH}=), 127.4(-\mathrm{CH}=), 113.8\left(-\mathrm{CO}_{2}-\right), 65.4$ and $65.0\left(-\mathrm{OCH}_{2}-\mathrm{CH}_{2} \mathrm{O}-\right), 57.5$ (-CO-CH-CO $\left.2-\right), 41.0$ (-CO-CH-CH-), 40.3 $\left(-\mathrm{CO}-\mathrm{CH}_{2}-\right), 36.6\left(-\mathrm{CH}_{2}-\mathrm{CH}_{2}-\mathrm{CH}=\right), 35.2 \quad\left(-\mathrm{CO}_{2}-\mathrm{CH}_{2}-\mathrm{CH}=\right), 29.1 \quad(-\mathrm{CO}-$ $\left.\mathrm{CH}_{2}-\mathrm{CH}_{2}-\right), 26.5\left(-\mathrm{CH}_{2}-\mathrm{CH}_{2}-\mathrm{CH}=\right)$. MS (+APCI): $(\mathrm{m} / z)=223\left(100,[\mathrm{MH}]^{+}\right)$, $179\left(21,[\mathrm{MH} \text {-acetaldehyde }]^{+}\right)$. IR (film, $\left.\mathrm{cm}^{-1}\right): v=3024 \mathrm{w}, 2956 \mathrm{~m}, 2928$ m, 2897 m, 2862 m, 1741 s, 1456 w, 1279 m, 1147 s, 1074 m, 1055 s, 966 m, 949 w, 912 m, 744 s. Elemental analysis for $\mathrm{C}_{13} \mathrm{H}_{18} \mathrm{O}_{3}(222.28)$ : calcd. C 70.24, H 8.16; found C 69.83, H 8.13.

\section{(Z)-1,2,5,6,9,9a-hexahydrospiro[cyclopenta[8] annulene-4,2'-}

\section{[1,3]dioxolan]-3(3aH)-one (27)}

Degassed DCE (14 ml), diene 26 (70 mg, $0.280 \mathrm{mmol}$, 1 eq.), 1,4 benzoquinone ( $3 \mathrm{mg}, 0.028 \mathrm{mmol}, 0.1$ eq.) and Grubbs 2 catalyst $(12 \mathrm{mg}$, $0.014 \mathrm{mmol}, 0.05$ eq.) are introduced in a three necked flask. The resulting solution is heated to reflux and stirred for 20 hours. The solution turns to blue. After this period, the mixture is concentrated under vacuum and a black residue is recovered. Purification (silica gel column, $\mathrm{PE} / \mathrm{Et}_{2} \mathrm{O}=8 / 2$ then horizontal distillation: $\left.170^{\circ} \mathrm{C}, 1 \mathrm{mbar}\right)$ affords $35 \mathrm{mg}(0.16 \mathrm{mmol})$ of a white solid. Yield $=57 \%$. ${ }^{1} \mathrm{H}$ NMR $\left(300 \mathrm{MHz}, \mathrm{CDCl}_{3}\right): \delta(\mathrm{ppm})=5.70$ $5.63\left(\mathrm{~m}, 1 \mathrm{H},-\mathrm{CH}_{2}-\mathrm{CH}_{2}-\mathrm{CH}=\right), 5.56-5.47\left(\mathrm{~m}, 1 \mathrm{H},-\mathrm{CH}_{2}-\mathrm{CH}_{2}-\mathrm{CH}=\mathrm{CH}-\right)$, 4.25-4.15 (m, $\left.1 \mathrm{H},-\mathrm{OCH}_{2}-\mathrm{CH}_{2} \mathrm{O}-\right)$, 3.99-3.85 (m, 3H, - $\left.-\mathrm{OCH}_{2}-\mathrm{CH}_{2} \mathrm{O}-\right), 2.85$ $\left(\mathrm{dt},{ }^{2} \mathrm{~J}=13.7 \mathrm{~Hz},{ }^{3} \mathrm{~J}=6.0 \mathrm{~Hz}, 1 \mathrm{H},-\mathrm{CH}-\mathrm{CH}_{2}-\mathrm{CH}=\right), 2.65-2.51(\mathrm{~m}, 2 \mathrm{H},(-\mathrm{CO}-$ $\mathrm{CH}-\mathrm{CH}-), 2.42-1.91(\mathrm{~m}, 7 \mathrm{H}), 1.88-1.57\left(\mathrm{~m}, 1 \mathrm{H},\left(-\mathrm{CO}-\mathrm{CH}_{2}-\mathrm{CH}_{2}-\right), 1.48-\right.$ $1.33\left(\mathrm{dtd},{ }^{2} \mathrm{~J}=12.1 \mathrm{~Hz},{ }^{3} \mathrm{~J}=11.9 \mathrm{~Hz},{ }^{3} \mathrm{~J}=8.4 \mathrm{~Hz}, 1 \mathrm{H},-\mathrm{CO}-\mathrm{CH}_{2}-\mathrm{CH}_{2}-\right) .{ }^{13} \mathrm{C}$ NMR (75 MHz, $\left.\mathrm{CDCl}_{3}\right): \delta(\mathrm{ppm})=215.3(\mathrm{C}=\mathrm{O}), 132.3(-\mathrm{CH}=), 123.5(-$ $\mathrm{CH}=), 111.3\left(-\mathrm{CO}_{2}-\right), 65.8$ and $64.9\left(-\mathrm{OCH}_{2}-\mathrm{CH}_{2} \mathrm{O}-\right), 57.7\left(-\mathrm{CO}-\mathrm{CH}-\mathrm{CO}_{2}-\right)$, 39.44 (-CO-CH${ }_{2-}^{-}, 39.40$ (-CO-CH- $\left.\mathrm{CH}-\right), 35.7\left(-\mathrm{CO}_{2}-\mathrm{CH}_{2-}\right), 30.1$ (-CH$\left.\mathrm{CH}_{2}-\mathrm{CH}=\right), 27.8\left(-\mathrm{CO}-\mathrm{CH}_{2}-\mathrm{CH}_{2}-\right), 25.5\left(-\mathrm{CO}_{2}-\mathrm{CH}_{2}-\mathrm{CH}_{2}-\right)$. MS (+APCI): $(m / z)=223\left(100,[\mathrm{MH}]^{+}\right), 179\left(19,[\mathrm{MH} \text {-acetaldehyde }]^{+}\right)$. IR (film, $\left.\mathrm{cm}^{-1}\right): v$ $=2955 \mathrm{~s}, 2926 \mathrm{~s}, 2897 \mathrm{~s}, 2874 \mathrm{~s}, 1743 \mathrm{~s}, 1473 \mathrm{w}, 1458 \mathrm{w}, 1338 \mathrm{w}, 1277 \mathrm{~m}$, $1201 \mathrm{~m}, 1151 \mathrm{~s}, 1061 \mathrm{~s}, 1038 \mathrm{~s}, 982 \mathrm{w}, 949$ m, 908 m. Elemental analysis of $\mathrm{C}_{13} \mathrm{H}_{18} \mathrm{O}_{3}$ (222.28): calcd. C 70.24, H 8.16; found C 69.61, H 8.09.

(Z)-8-methyl-1,2,5,6,9,9a-hexahydrospiro[cyclopenta[8] annulene-4,2'[1,3]dioxolan]-3(3aH)-one (31): Degassed DCE $(380 \mathrm{ml})$, diene $(2.00 \mathrm{~g}$, $7.560 \mathrm{mmol}, 1$ eq.), 1,4-benzoquinone $(82 \mathrm{mg}, 0.756 \mathrm{mmol}, 0.1$ eq. $)$ and Grubbs 2 catalyst ( $321 \mathrm{mg}, 0.378 \mathrm{mmol}, 0.05$ eq.) are introduced in a three necked flask. The resulting solution is heated to reflux and stirred for 48 hours. After this period, a second portion of 1,4 benzoquinone $(82 \mathrm{mg})$ and Grubbs $2(321 \mathrm{mg})$ is added. The resulting solution is heated to reflux and stirred for additional 48 hours. The mixture is concentrated under vacuum and a black residue is recovered. Purification (silica gel column, $\mathrm{PE} / \mathrm{Et}_{2} \mathrm{O}=$ $8 / 2$ ) affords $1.158 \mathrm{~g}$ of an inseparable mixture of $\mathbf{3 1}$ and $\mathbf{3 2}(\mathbf{3 2} / \mathbf{3 1}=1.25: 1)$. Epoxides (44) and (45): DCM (4 ml), alkene $27(57 \mathrm{mg}, 0.256 \mathrm{mmol}$, eq.), $\mathrm{NaHCO}_{3}$ (43 mg, $0.512 \mathrm{mmol}, 2$ eq.) and mCPBA (70\% purity, 126 
$\mathrm{mg}, 0.512 \mathrm{mmol}, 2$ eq.) are introduced in a round bottomed flask. The resulting solution is stirred at room temperature for 15 hours. The mixture is washed with $\mathrm{NaOH} 5 \%(3 \times 15 \mathrm{ml})$, dried over $\mathrm{MgSO}_{4}$ and concentrated under vacuum. Purification (silica gel column, $\mathrm{Et}_{2} \mathrm{O} / \mathrm{PE}=8 / 2$ ) affords 56 $\mathrm{mg}(0.235 \mathrm{mmol})$ of a white solid. Yield $=92 \%$. Two diastereoisomers are isolated in a $1.24 / 1$ ratio $((44)=31 \mathrm{mg},(45)=25 \mathrm{mg}) .{ }^{1} \mathrm{H}$ NMR $(300 \mathrm{MHz}$, $\left.\mathrm{CDCl}_{3}\right):(44): \delta(\mathrm{ppm})=4.17-4.11\left(\mathrm{~m}, 1 \mathrm{H},-\mathrm{OCH}_{2}-\mathrm{CH}_{2} \mathrm{O}-\right), 4.03-3.99(\mathrm{~m}$, $2 \mathrm{H},-\mathrm{OCH}_{2}-\mathrm{CH}_{2} \mathrm{O}-$ ), 3.75 (q, J $=6.8 \mathrm{~Hz}, 1 \mathrm{H},-\mathrm{OCH}_{2}-\mathrm{CH}_{2} \mathrm{O}-$ ), 3.09 (ddd, J = $11.2 \mathrm{~Hz} ; \mathrm{J}=4.1 \mathrm{~Hz} ; \mathrm{J}=3.4 \mathrm{~Hz}, 1 \mathrm{H}, \mathrm{HC}-\mathrm{O}-\mathrm{CH}), 2.49-2.05(\mathrm{~m}, 5 \mathrm{H}), 1.93$ (ddd, $\mathrm{J}=12.8 \mathrm{~Hz}, \mathrm{~J}=6.0 \mathrm{~Hz}, \mathrm{~J}=1.7 \mathrm{~Hz}, 1 \mathrm{H},-\mathrm{CH}-\mathrm{CH}-\mathrm{O}-$ ), 1.74-1.17 (m, $5 \mathrm{H})$. (45): $\delta(\mathrm{ppm})=4.10-4.02\left(\mathrm{~m}, 1 \mathrm{H},-\mathrm{OCH}_{2}-\mathrm{CH}_{2} \mathrm{O}-\right), 3.99-3.84(\mathrm{~m}, 3 \mathrm{H}$, $\left.\mathrm{OCH}_{2}-\mathrm{CH}_{2} \mathrm{O}-\right)$, 3.10-3.03 (m, 1H, - HC-O-CH-), 2.87-2.76 (m, 1H, - HC-O$\mathrm{CH}-), 2.58-2.02(\mathrm{~m}, 9 \mathrm{H}), 1.89$ (ddd, $\mathrm{J}=14.9 \mathrm{~Hz}, \mathrm{~J}=10.8 \mathrm{~Hz}, \mathrm{~J}=1.9 \mathrm{~Hz}$, $\left.1 \mathrm{H},-\mathrm{CH}_{2}-\mathrm{CH}-\mathrm{O}-\right), 1.61-1.41\left(\mathrm{~m}, 2 \mathrm{H},-\mathrm{CO}-\mathrm{CH}_{2}-\mathrm{CH}_{2}-\right) .{ }^{13} \mathrm{C} \mathrm{NMR}(75 \mathrm{MHz}$, $\left.\mathrm{CDCl}_{3}\right):(44): \delta(\mathrm{ppm})=216.6(\mathrm{C}=\mathrm{O}), 111.5\left(-\mathrm{CO}_{2}-\right), 65.4$ and $65.1(-$ $\left.\mathrm{OCH}_{2}-\mathrm{CH}_{2} \mathrm{O}-\right), 59.1$ (-CO-CH-CO $\left.{ }_{2}^{-}\right), 54.4$ and $52.6(-\mathrm{CH}-\mathrm{O}-\mathrm{CH}-), 39.7$ ($\mathrm{CO}-\mathrm{CH}-\mathrm{CH}-), 40.3,35.0,32.2,29.1,28.5 .(45): \delta(\mathrm{ppm})=214.6(\mathrm{C}=\mathrm{O})$, $110.7\left(-\mathrm{CO}_{2-}\right), 65.4$ and $64.8\left(-\mathrm{OCH}_{2}-\mathrm{CH}_{2} \mathrm{O}-\right), 57.2\left(-\mathrm{CO}-\mathrm{CH}-\mathrm{CO}_{2}-\right), 55.4$ and 54.6 (-CH-O-CH-), 39.7 (-CO-CH-CH-), 35.6, 32.4, 30.9, 27.9, 22.5. MS (+ESI): $(m / z)=279\left(100,\left[\mathrm{M}+\mathrm{Na}+\mathrm{H}_{2} \mathrm{O}\right]^{+}\right), 261\left(9,[\mathrm{M}+\mathrm{Na}]^{+}\right), 239(7$, $\left.[\mathrm{MH}]^{+}\right)$. MS (+APCI): $(\mathrm{m} / \mathrm{z})=239\left(65,[\mathrm{MH}]^{+}\right), 221\left(32,\left[\mathrm{MH}-\mathrm{H}_{2} \mathrm{O}\right]^{+}\right), 195$ (34, [MH-acetaldehyde $\left.]^{+}\right), 177\left(100,\left[\mathrm{MH}-\mathrm{H}_{2} \mathrm{O} \text {-acetaldehyde }\right]^{+}\right)$. IR (film, $\left.\mathrm{cm}^{-1}\right): v=2921 \mathrm{~s}, 2852 \mathrm{~s}, 1736 \mathrm{~s}, 1458 \mathrm{~m}, 1410 \mathrm{w}, 1377 \mathrm{w}, 1332 \mathrm{w}, 1308$ w, 1284 w, 1147 s, 1068 s, 1041 s, 949 s, 912 m. HRMS (+CI): calcd. for $[\mathrm{MH}]^{+}\left(\mathrm{C}_{13} \mathrm{H}_{19} \mathrm{O}_{4}\right): 239.12833$, found: 239.12846 .

\section{4-hydroxyhexahydro-2H-spiro[cyclopenta[c]pentalene-1,2'-}

[1,3]dioxolan]-8(3H)-one (46): THF (4.5 ml) and epoxide 45 (32 $\mathrm{mg}$, $0.134 \mathrm{mmol}, 1$ eq.) are introduced in a round-bottomed flask. Then, $\mathrm{NaH}$ ( $60 \%$ in paraffin, $11 \mathrm{mg}, 0.27 \mathrm{mmol}, 2$ eq.) is added in one portion. After gas evolution, the reaction mixture is heated to reflux during 3 hours. After cooling, the solution is quenched with $\mathrm{NH}_{4} \mathrm{Cl}$ (sat. aq., $3 \mathrm{ml}$ ). The aqueous phase is extracted with AcOEt $(5 \times 3 \mathrm{ml})$. The combined organic fractions are dried over $\mathrm{MgSO}_{4}$ and concentrated under reduced pressure. Purification (silica gel column, $\left.\mathrm{PE} / \mathrm{Et}_{2} \mathrm{O}=1 / 9\right)$ affords $16 \mathrm{mg}(0.067 \mathrm{mmol})$ of colorless oil. Yield $=50 \%$. ${ }^{1} \mathrm{H}$ NMR $\left(300 \mathrm{MHz}, \mathrm{CDCl}_{3}\right): \delta(\mathrm{ppm})=4.13$ $\left(\mathrm{dt},{ }^{3} \mathrm{~J}=9.9 \mathrm{~Hz},{ }^{3} \mathrm{~J}=5.1 \mathrm{~Hz}, 1 \mathrm{H},-\mathrm{CH}-\mathrm{OH}\right), 3.99-3.95\left(\mathrm{~m}, 2 \mathrm{H},-\mathrm{OCH}_{2}-\right.$ $\left.\mathrm{CH}_{2} \mathrm{O}-\right), 3.89-3.85\left(\mathrm{~m}, 2 \mathrm{H},-\mathrm{OCH}_{2}-\mathrm{CH}_{2} \mathrm{O}-\right), 2.84\left(\mathrm{dq},{ }^{3} \mathrm{~J}=7.4 \mathrm{~Hz},{ }^{3} \mathrm{~J}=4.3\right.$ $\left.\mathrm{Hz}, 1 \mathrm{H},-\mathrm{CH}_{2}-\mathrm{CH}-\mathrm{CH}_{2}-\right), 2.69\left(\mathrm{ddd},{ }^{3} \mathrm{~J}=9.8 \mathrm{~Hz},{ }^{3} \mathrm{~J}=6.4 \mathrm{~Hz},{ }^{3} \mathrm{~J}=3.6 \mathrm{~Hz}\right.$, $1 \mathrm{H}, \mathrm{HO}-\mathrm{CH}-\mathrm{CH}-$ ), $2.61\left(\mathrm{bd},{ }^{3} \mathrm{~J}=10.6 \mathrm{~Hz}, 1 \mathrm{H},-\mathrm{OH}\right), 2.36-2.29(\mathrm{~m} \mathrm{3H},-$ $\left.\mathrm{CO}-\mathrm{CH}_{2-},-\mathrm{CH}_{2}-\mathrm{CH}-\mathrm{OH}\right), 2.04-1.89(\mathrm{~m}, 4 \mathrm{H}), 1.71-1.52\left(\mathrm{~m}, 2 \mathrm{H},-\mathrm{CO}_{2}-\mathrm{CH}_{2-}\right.$ $\left.\mathrm{CH}_{2}-\right), 1.46-1.32\left(\mathrm{~m}, 1 \mathrm{H},-\mathrm{CO}-\mathrm{CH}_{2}-\mathrm{CH}_{2}-\right) .{ }^{13} \mathrm{C} \mathrm{NMR}\left(75 \mathrm{MHz}, \mathrm{CDCl}_{3}\right): \delta$ $(\mathrm{ppm})=219.4(\mathrm{C}=\mathrm{O}), 117.7\left(-\mathrm{CO}_{2}-\right), 71.6\left(\mathrm{C}_{\text {quat }}\right), 71.2(-\mathrm{CH}-\mathrm{OH}), 65.0$ and $64.8\left(-\mathrm{OCH}_{2}-\mathrm{CH}_{2} \mathrm{O}-\right), 54.9$ (HO-CH-CH-), $45.0\left(-\mathrm{CH}_{2}-\mathrm{CH}-\mathrm{OH}\right), 43.3(-$ $\left.\mathrm{CH}_{2}-\mathrm{CH}-\mathrm{CH}_{2-}\right), 39.9$ (-CO- $\left.\mathrm{CH}_{2-}\right), 34.8\left(-\mathrm{CO}_{2}-\mathrm{CH}_{2-}\right), 24.8\left(-\mathrm{CO}_{2}-\mathrm{CH}_{2}-\mathrm{CH}_{2-}\right.$ ), $23.7\left(-\mathrm{CO}-\mathrm{CH}_{2}-\mathrm{CH}_{2}-\right)$. MS (+ESI): $(\mathrm{m} / \mathrm{z})=261\left(100,[\mathrm{M}+\mathrm{Na}]^{+}\right), 239(39$, $\left.[\mathrm{MH}]^{+}\right), 221\left(44,\left[\mathrm{MH}-\mathrm{H}_{2} \mathrm{O}\right]^{+}\right), 177\left(19,\left[\mathrm{MH}-\mathrm{H}_{2} \mathrm{O} \text {-acetaldehyde }\right]^{+}\right) . \mathrm{MS}$ $(+\mathrm{APCI}):(\mathrm{m} / \mathrm{z})=239\left(14,[\mathrm{MH}]^{+}\right), 221\left(100,\left[\mathrm{MH}-\mathrm{H}_{2} \mathrm{O}\right]^{+}\right), 177(94,[\mathrm{MH}-$ $\mathrm{H}_{2} \mathrm{O}$-acetaldehyde $]^{+}$). IR (film, $\mathrm{cm}^{-1}$ ): $v=3430 \mathrm{bm}, 2951 \mathrm{~m}, 2878 \mathrm{~m}, 1730$ s, $1456 \mathrm{w}, 1412 \mathrm{w}, 1314 \mathrm{~m}, 1283 \mathrm{~m}, 1200 \mathrm{~m}, 1167 \mathrm{~m}, 1146 \mathrm{~m}, 1117 \mathrm{~m}$, $1096 \mathrm{~m}, 1059 \mathrm{~m}, 1032 \mathrm{~m}, 951 \mathrm{~m}$. HRMS (+ESI): calcd. for [M+Na] $\left(\mathrm{C}_{13} \mathrm{H}_{18} \mathrm{O}_{4} \mathrm{Na}\right)$ : 261.1103, found: 261.1099.

Supporting Information (see footnote on the first page of this article): Synthetic procedures and characterisation for orthoesters, silylenol ethers and dienes.

\section{Acknowledgments}

Financial support of this work by the Universite catholique de Louvain, the Fonds pour la Recherche dans l'Industrie et l'Agriculture (F.R.I.A., studentship to G.D.B.) and the Actions de Recherche Concertées (ARC 08/13-012) is gratefully acknowledged.

${ }^{[1][1 a]}$ First generation: P. Schwab, M. B. France, J. W. Ziller, R. H. Grubbs, Angew. Chem. Int. Ed. 1995, 34, 2039-2041. Second generation: [1b] J. Huang, E. D. Stevens, S. P. Nolan, J. L. Petersen, J. Am. Chem. Soc. 1999, 121, 2674-2678. ${ }^{[1 \mathrm{c}]}$ M. Scholl, T. M. Trnka, J. P. Morgan, R. H. Grubbs, Tetrahedron Letters 1999, 40, 2247-2250. ${ }^{[1 \mathrm{~d}]}$ L. Ackermann, A. Fürstner, T. Weskamp, F. J. Kohl, W. A. Herrmann, Tetrahedron Letters 1999, 40, 4787-4790. ${ }^{[1 \mathrm{e}]}$ M. Scholl, S. Ding, C. W. Lee, R. H. Grubbs, Org. Lett. 1999, 1, 953-956.

${ }^{[2]}$ Selected reviews: ${ }^{[2 a]}$ G. C. Vougioukalakis, R. H. Grubbs, Chem. Rev. 2010, 110, 1746-1787. ${ }^{[2 b]}$ C. W. Bielawski, R. H. Grubbs, Prog. Polym.
Sci. 2007, 32, 1-29. ${ }^{[2 c]}$ J. C. Conrad, D. E. Fogg, Curr Org Chem 2006, 10 185-202. ${ }^{[2 \mathrm{~d}]}$ K. C. Nicolaou, P. G. Bulger, D. Sarlah, Angew. Chem. Int Ed. 2005, 44, 4490-4527. ${ }^{[2 \mathrm{e}]}$ R. H. Grubbs, Tetrahedron 2004, 60, 71177140. ${ }^{[2 f]}$ T. M. Trnka, R. H. Grubbs, Acc. Chem. Res. 2001, 34, 18-29. ${ }^{[2 \mathrm{~g}]}$ A. Fürstner, Angew. Chem. Int. Ed. 2000, 39, 3012-3043. ${ }^{[2 \mathrm{~h}]}$ R. H. Grubbs, S. Chang, Tetrahedron 1998, 54, 4413-4450.

[3] [3a] M. E. Maier, Angew. Chem. Int. Ed. 2000, 39, 2073-2077. ${ }^{[3 b]}$ A. Michaut, J. Rodriguez Angew. Chem. Int. Ed. 2006, 45, 5740-5750.

${ }^{[4]}$ A. Fürstner, O. R. Thiel, L. Ackermann, H.-J. Schanz, S. P. Nolan, J. Org. Chem. 2000, 65, 2204-2207.

${ }^{[5]}$ H. D. Maynard, R. H. Grubbs, Tetrahedron Lett. 1999, 40, 4137-4140.

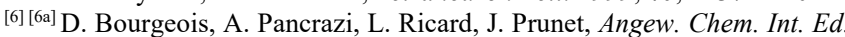
2000, 39, 725-728. ${ }^{[6 \mathrm{~b}]}$ D. Bourgeois, A. Pancrazi, S. P. Nolan, J. Prunet, $J$. Organomet. Chem. 2002, 643-644, 247-252. ${ }^{[6 \mathrm{c}]}$ C. Ma, S. Schiltz, X. F. Le Goff, J. Prunet, Chem. Eur. J. 2008, 14, 7314-7323.

${ }^{[7]}$ Minireview on this topic : B. Schmidt, Eur. J. Org. Chem. 2004, 18651880 .

${ }^{[8][8 \mathrm{a}]}$ T. J. Donohoe, T. J. C. ORiordan, C. P. Rosa, Angew. Chem. Int. Ed. 2009, 48, 1014. ${ }^{[8 b]}$ S. Hanessian, S. Giroux, A. Larsson, Org. Lett. 2006, 8, 5481. ${ }^{[8 c]}$ B. Schmidt, J. Mol. Cat. A 2006, 254, 53. ${ }^{[8 \mathrm{~d}]}$ Schmidt, B.; Staude, L. J. Organomet. Chem. 2006, 691, 5218. ${ }^{[8 \mathrm{e}]}$ B. Schmidt, Eur. J. Org. Chem. 2003, 816. ${ }^{[8 f]}$ W. A. L. van Otterlo, R. Pathak, C. B. de Koning, Synlett 2003, 12, 1859. ${ }^{[\mathrm{gg}]}$ A. E. Sutton, B. A. Seigal, D. F. Finnegan, M. L. Snapper, J. Am. Chem. Soc. 2002, 124, 13390-13391.

${ }^{[9]}{ }^{[9]}$ C. D. Edlin, J. Faulkner, D. Fengas, C. K. Knight, J. Parker, I. Preece, P. Quayle, S. N. Richards, Synlett 2005, 4, 572. ${ }^{[96]}$ F. C. Courchay, J. C. Sworen, I. Ghiviriga, K. A. Abboud, K. B. Wagener, Organomettalics 2006, 25,6074 .

${ }^{[10]}$ See ref. ${ }^{[2 \mathrm{~g}]}$

${ }^{[11]}$ See ref. ${ }^{[8 \mathrm{~g}]}$

${ }^{[12]}{ }^{12 a]}$ Postulated mechanism on similar complex: Z. Wu, S. B. T. Nguyen, R. H. Grubbs, J. W. Ziller J. Am. Chem. Soc. 1995, 117, 5503-5511. [12b Isolation of 3: J. Louie, R. H. Grubbs Organometallics 2002, 21, 21532164. ${ }^{[12 c]}$ Mechanistic study on the formation of 3: M. B. Dinger, J. C. Mol, Organometallics 2003, 22, 1089-1095. [12d] Mechanistic study on the formation of 4: M. B. Dinger, J. C. Mol, Eur. J. Inorg. Chem. 2003, 28272833. ${ }^{[12 \mathrm{e}]}$ Use of $\mathbf{3}$ as alkene hydrogenation catalyst: C. S. Yi, D. W. Lee Organometallics 1999, 18, 5152-5156. [12f] Use of $\mathbf{4}$ as alkene hydrogenation catalyst: H. M. Lee, D. C. Smith Jr., Z. He, E. D. Stevens, C. S. Yi, S. P. Nolan Organometallics 2001, 20, 794-797.

${ }^{[13]}$ S. H. Hong, M. W. Day, R. H. Grubbs, J. Am. Chem. Soc. 2004, 126, 7414-7415.

${ }^{[14]}{ }^{[14 a]} \mathrm{OPCy}_{3}$ : see ref. ${ }^{[4 b]}{ }^{[14 b]}$ Benzoquinones : S. H. Hong, D. P. Sanders, C. W. Lee, R. H. Grubbs, J. Am. Chem. Soc. 2005, 127, 17160-17161. ${ }^{[14 c]}$ Phenylphosphoric acid : N. Gimeno, P. Formentín, J. H. G. Steinke, R. Vilar, Eur. J. Org. Chem. 2007, 918-924. ${ }^{[14 \mathrm{~d}]} \mathrm{SnX}_{2}$ : W. H. Meyer, A. E. McConnell, G. S. Forman, C. L. Dwyer, M. M. Kirk, E. L. Ngidi, A. Blignaut, D. Saku, A. M. Z. Slawin, Inorg. Chem. Acta. 2006, 359, 2910 2917. ${ }^{[14 d]}$ For the use of microwaves to enhance the rate of metathesis reactions see: Y. Coquerel, J. Rodriguez Eur. J. Org. Chem. 2008, 1125 1132 .

${ }^{[15]}{ }^{[15 a]}$ I. E. Markó, A. Ates, Synlett 1999, 7, 1033-1036. ${ }^{[15 b]}$ I. E. Markó, J.-C. Vanherk, A. Ates, B. Tinant, J.-P. Declercq, Tetrahedron Lett. 2003 44, 3333-3336. ${ }^{[15 c]}$ N. Maulide, J.-C. Vanherk, I. E. Markó, Eur. J. Org. Chem. 2004, 3962-3967. ${ }^{[15 \mathrm{~d}]}$ C. De Dobbeleer, A. Ates, J.-C. Vanherk, I. E. Markó, I. E. Tetrahedron Lett. 2005, 46, 3889-3893. ${ }^{[15 \mathrm{e}]}$ N. Maulide, I. E. Markó, Org. Lett. 2006, 8(17), 3705-3707. ${ }^{[15 f]}$ N. Maulide, I. E. Markó, Org. Lett. 2007, 9(19), 3757-3760.

${ }^{[16]}$ See ref. ${ }^{[1 b-e]}$

${ }^{[17]}$ S. H. Hong, A. G. Wenzel, T. T. Salguero, M. W. Day, R. H. Grubbs, J. Am. Chem. Soc. 2007, 129, 7961-7968.

[18] For other example of substrate induce metathesis/isomerisation competition, see: ${ }^{[18 a]}$ M. Michalak, J. Wicha Synlett 2005, 15, 2277-2280. ${ }^{[18 b]}$ B. Schmidt, A. Biernat Synlett 2007, 15, 2375-2378.

[19] Various Lewis acids have been proved to supress this undesired coordination: ${ }^{[19 a]} \mathrm{Ti}(\mathrm{O} i \mathrm{Pr})_{4}$ see A. Fürstner, K. Langemann, J. Am. Chem.

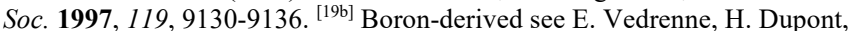
S. Oualef, L. Elkaïm, L. Grimaud Synlett 2005, 4, 670-672.

Received: ((will be filled in by the editorial staff))

Published online: ((will be filled in by the editorial staff)) 
Entry for the Table of Contents ((Please choose one layout.))

\section{Layout 2:}

Ring closing metathesis

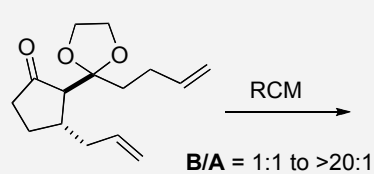

$B / A=1: 1$ to $>20: 1$

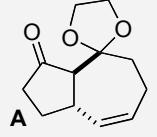

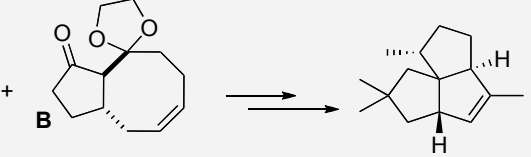

Benzoquinone derivatives have been shown to dramatically decrease the isomerisation process. A highly functionalised triquinane intermediate for the synthesis of Pentalenene has been reached.
The Grubbs 2 catalysed RCM of various bis-olefinic precursors leads to the formation of isomerised products. The isomerisation phenomenon has been studied in a substrate perspective.

\section{Guillaume De Bo, Istvàn Markò*} Page No. - Page No.

Studies towards the synthesis of Pentalenene: mechanistic insights on the isomerisation phenomenon during RCM of medium sized rings.

Keywords: RCM / Medium sized rings / Isomerisation / Grubbs catalyst / Pentalenene 